Images in...

\title{
Endoscopic transnasal retrieval of an airgun pellet lodged in the orbital apex
}

\author{
Mariya Moosajee, ${ }^{1}$ Tasanee Braithwaite, ${ }^{2}$ William Grant, ${ }^{3}$ Veronica Ferguson ${ }^{1}$ \\ ${ }^{1}$ Department of Ophthalmology, Charing Cross Hospital, London, UK \\ ${ }^{2}$ Department of Ophthalmology, Chelsea and Westminster Hospital, London, UK \\ ${ }^{3}$ ENT Department, Charing Cross Hospital, London, UK
}

Correspondence to Tasanee Braithwaite, tasaneebraithwaite@gmail.com

\section{DESCRIPTION}

A 17-year-old boy presented to eye casualty complaining of loss of vision in the right eye after being shot at close range in the right nasolabial fold with an airgun rifle (figure $1 \mathrm{~A}$ ). The right eye perceived light only (left visual acuity 6/5) with a relative afferent pupillary defect but otherwise normal examination. CT of the orbits and brain revealed a pellet lodged against the right optic nerve within the superior orbital fissure (figure 1B). The patient was started on pulsed high-dose intravenous methylprednisolone within 8 $h$ and the pellet was retrieved from the orbital apex the next day via endoscopic transnasal approach with optic nerve decompression (figure 1C). Three months post-injury, examination revealed a right traumatic optic atrophy (figure 1D) with subtle improvement to "hand movements' vision. The estimated incidence of ocular airgun injuries in the UK is $91-115$ cases per year; $90 \%$ of victims are men, mean age is 17.5 years and only $23 \%$ of injuries are deliberate. ${ }^{1}$ Literature review indicates early administration of high-dose steroids remains controversial with infrequent but notable complications. ${ }^{2}$ Endoscopic transnasal approach improves visualisation and access to foreign bodies within the orbit making it a relatively safe technique. ${ }^{3}$ However, the visual prognosis remains poor if the

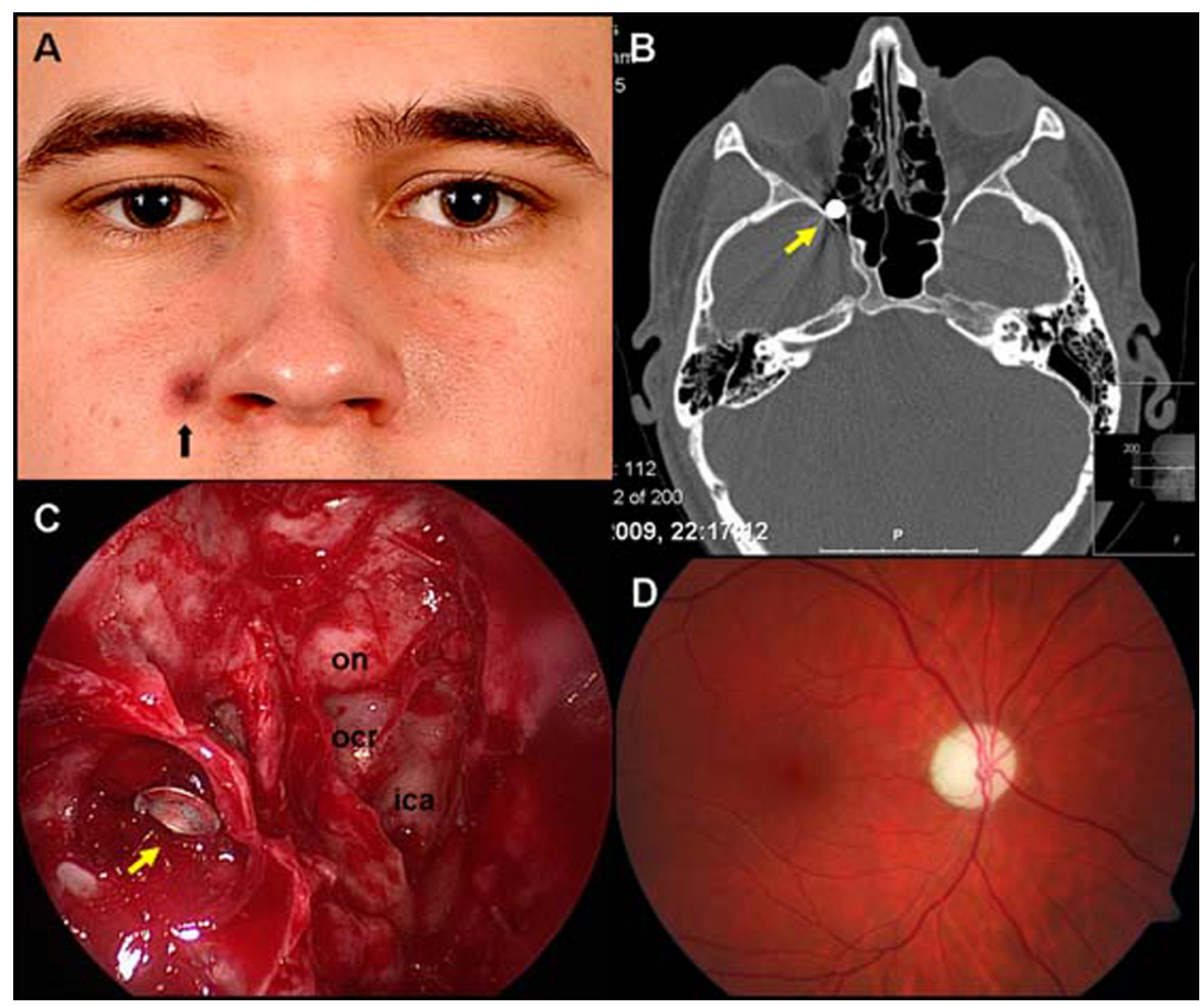

Figure 1 (A) Airgun pellet entry wound (5 mm diameter) at the right nasolabial fold (black arrow); (B) CT of the orbits and brain showing the airgun pellet in the right orbit (yellow arrow); (C) endoscopic dissection to identify the pellet $(11 \times 6 \mathrm{~mm}$, yellow arrow) lodged in the orbital apex through the superomedial antral wall abutting the optic nerve (on); (D) 3 months post-injury right fundal view reveals traumatic optic atrophy. ica, internal carotid artery; ocr, optico-carotid recess. 


\section{BMJ Case Reports}

presenting visual acuity is poor. ${ }^{1}{ }^{2}$ A prospective randomised trial is required to assess the use of early steroids versus early surgical removal of the airgun pellet. Currently, urgent referral for joint care between ophthalmology and ear, nose and throat permits optimal management of orbital injuries.

\section{Competing interests None.}

Patient consent Obtained.

\section{REFERENCES}

1. Shuttleworth GN, Galloway P, Sparrow JM, et al. Ocular air gun injuries: a one-year surveillance study in the UK and Eire (BOSU). 2001-2002. Eye (Lond) 2009;23:1370-6.

2. Yu-Wai-Man $\mathbf{P}$, Griffiths PG. Steroids for traumatic optic neuropathy. Cochrane Database Syst Rev 2007:4:CD006032.

3. Khan-Lim D, Ellis J, Saleh H, et al. Endoscopic transnasal removal of orbital foreign body. Eye (Lond) 1999;13(Pt 5):667-8.

This pdf has been created automatically from the final edited text and images.

Copyright 2010 BMJ Publishing Group. All rights reserved. For permission to reuse any of this content visit

http://group.bmj.com/group/rights-licensing/permissions.

BMJ Case Report Fellows may re-use this article for personal use and teaching without any further permission.

Please cite this article as follows (you will need to access the article online to obtain the date of publication).

Moosajee M, Braithwaite T, Grant W, Ferguson V. Endoscopic transnasal retrieval of an airgun pellet lodged in the orbital apex. BMJ Case Reports 2010; 10.1136/bcr.07.2010.3159, date of publication

Become a Fellow of BMJ Case Reports today and you can:

- Submit as many cases as you like

Enjoy fast sympathetic peer review and rapid publication of accepted articles

Access all the published articles

Re-use any of the published material for personal use and teaching without further permission

For information on Institutional Fellowships contact consortiasales@bmjgroup.com

Visit casereports.bmj.com for more articles like this and to become a Fellow 